\title{
Coffee consumption is correlated with serum cholesterol in middle-aged Finnish men and
} women

\author{
JAAKKO TUOMILEHTO, ${ }^{1}$ ANTTI TANSKANEN, ${ }^{2}$ PIRJO PIETINEN, ${ }^{1}$ ANTTI \\ ARO, ${ }^{1}$ JUKKA T SALONEN, ${ }^{2}$ PERTTI HAPPONEN, ${ }^{2}$ AULIKKI NISSINEN, ${ }^{1}$ AND \\ PEKKA PUSKA ${ }^{1}$
}

From the National Public Health Institute, ${ }^{1}$ Mannerheimintie 166,00280 Helsinki, Finland and the Department of Community Health, 2 University of Kuopio, PO Box 6, 70210 Kuopio, Finland

SUMMARY The association between coffee consumption and serum cholesterol was studied in a cross-sectional epidemiological study in Finland where the annual per capita consumption of coffee $(13.0 \mathrm{~kg})$ is the highest in the world. Coffee consumption was assessed by a questionnaire in a representative population sample of 4744 men and 4495 women aged 25 to 64 years. Serum total cholesterol and HDL-cholesterol concentrations were determined in fresh sera by the enzymatic method. Data on a large number of potential confounding variables were also collected. In the age group 25 to 44 years, the level of serum total cholesterol increased linearly with increasing coffee consumption in both sexes, but in people aged 45 to 64 the peak level of serum cholesterol was found in those who consumed 4 to 6 cups of coffee per day. In the analysis of covariance controlling for age, body mass index, intake of fat, sugar, and alcohol, smoking, physical activity, and fasting time, the mean level of serum cholesterol of men was lower $(p<0.001)$ in those who drank no coffee $(5.9$ $\mathrm{mmol} / \mathrm{l})$ than in those who drank 1 to 3 cups $(6 \cdot 1 \mathrm{mmol} / \mathrm{l})$ or 4 or more cups $(6 \cdot 2 \mathrm{mmol} / \mathrm{l})$ per day. In women, the corresponding mean serum cholesterol values were $5.8 \mathrm{mmol} / \mathrm{l}, 6 \cdot 1 \mathrm{mmol} / \mathrm{l}$, and $6 \cdot 1$ $\mathrm{mmol} / \mathrm{l}(\mathrm{p}<0.05)$. Serum HDL-cholesterol levels did not vary significantly with coffee consumption. There was a slight inverse association between tea drinking and serum total cholesterol in men $(p<0.05)$ but not in women. Although our results suggest a positive association, the impact of coffee drinking on serum cholesterol seems to be minimal. The results also indicate that the possible mechanisms do not include caffeine.

The possible association between coffee drinking and serum cholesterol level has aroused much interest during recent years. Several cross-sectional studies have reported a positive association between coffee consumption and serum cholesterol ${ }^{1-5}$ but there are also studies that showed no association. ${ }^{6-9}$ In some studies the association has been found only in women, ${ }^{10-13}$ in smokers, ${ }^{14}$ or in young people. ${ }^{15}$ There was a negative correlation between the consumption of tea and serum cholesterol in one study. ${ }^{16}$ According to trade statistics, the average annual consumption of coffee per capita in Finland was $13.0 \mathrm{~kg}$ in 1979-83 (corresponding to 5 to 6 cups per day) which is the highest in the world. ${ }^{17}$ Serum cholesterol levels in Finland are higher than in most other populations in the world, and the mortality from cardiovascular diseases is one of the highest. ${ }^{18}$ Therefore we considered it important to analyse the associations between coffee consumption and serum cholesterol concentration in this particular population using available data from a recent population study.

\section{Material and methods}

A large population survey was carried out in eastern and south-western Finland in the spring of 1982. This survey served both as the 10 year follow-up survey of the North Karelia project ${ }^{18}$ and as the baseline survey of the FINMONICA project monitoring various cardiovascular risk factors. A random sample of the age group 25 to 64 years was drawn in three areas (North Karelia county and Kuopio county in eastern Finland and the Turku-Loimaa area in south-western Finland) stratified for sex and each 10 year age group. 
Table 1 Coffee drinking habits among middle-aged Finnish men and women by age (\%)

\begin{tabular}{|c|c|c|c|c|c|c|c|c|c|c|c|c|c|c|}
\hline \multirow[b]{2}{*}{ Age group (yr) } & \multicolumn{7}{|c|}{$\begin{array}{l}\text { Men } \\
\text { Cups of coffee per day }\end{array}$} & \multicolumn{7}{|c|}{$\begin{array}{l}\text { Women } \\
\text { Cups of coffee per day }\end{array}$} \\
\hline & 0 & $1-3$ & $4-6$ & $7-9$ & $>10$ & Mean $+S D$ & $(N)$ & 0 & $1-3$ & $4-6$ & $7-9$ & $>10$ & Mean + SD & $(N)$ \\
\hline $25-34$ & 5 & 21 & 43 & 16 & 16 & $5.7+3.6$ & (1123) & 6 & 26 & 51 & 11 & 5 & $4 \cdot 6+2 \cdot 6$ & $(1068)$ \\
\hline $35-34$ & 5 & 20 & 44 & 16 & 15 & $5 \cdot 7+3 \cdot 4$ & (1186) & 5 & 22 & 52 & 14 & 8 & $5 \cdot 0+2 \cdot 7$ & (1171) \\
\hline $45-54$ & 5 & 20 & 48 & 14 & 13 & $5.4+3.0$ & (1135) & 4 & 22 & 56 & 11 & 7 & $4 \cdot 9+2 \cdot 5$ & (1184) \\
\hline $55-64$ & 5 & 19 & 52 & 12 & 11 & $5 \cdot 4+2.9$ & (1090) & 4 & 23 & 61 & 10 & 4 & $4 \cdot 7+2 \cdot 3$ & (1272) \\
\hline Total & 5 & 20 & 46 & 15 & 14 & $5 \cdot 6+3 \cdot 3$ & (4534) & 5 & 23 & 55 & 11 & 6 & $4 \cdot 8+2 \cdot 5$ & (4695) \\
\hline
\end{tabular}

Number of subjects in parentheses

This procedure was based on the protocol of the international MONICA project initiated by the World Health Organization. ${ }^{19}$ The participation rate was $80 \%$ in North Karelia, $83 \%$ in Kuopio, and $84 \%$ in south-western Finland. The total number of participants was 9347.

The survey included a questionnaire mailed to the subjects and returned to the screening site, and a fasting venous blood sample for determination of serum cholesterol concentration. The questionnnaire included the question: "How many cups of coffee or tea do you usually drink daily?"

A qualitative intake score of saturated fat was calculated based on the following: use of cream in coffee, type of fat used in cooking, type of fat used in baking, type and amount of fat used on bread, eating visible pork fat, and type and amount of milk used daily. The maximum value of this index was $13 .{ }^{20}$

The amount of smoking was defined as the number of cigarettes, cigars, and pipefuls of tobacco smoked per day. Alcohol consumption was assessed by asking subjects the amount of spirits, wine, and beer that they had consumed during the week prior to the survey, This was subsequently transformed into weekly consumption of ethanol.

Data on physical activity at work and during leisure time were collected by precoded, standardised questions which gave scores from 1 to 4 separately for both components of physical activity. ${ }^{2}$ These two variables were then combined to form a score which varied between 0 and 6 where the higher values indicated the most strenuous physical activity.

Serum cholesterol and HDL-cholesterol were determined from fresh sera by the CHOD-PAP enzymatic method (kit number 236691, BoehringerMannheim GmbH, FRG), HDL-cholesterol was measured after dextran sulphate-magnesium chloride precipitation $^{22}$ in the Department of Biochemistry of the National Public Health Institute in Helsinki.

Statistical analyses of the data were done using the SPSS package. The Pearson product-moment correlation analysis and multiple regression analysis with the step up procedure were done in order to study the association of coffee and tea drinking with a large number of other parameters, putative confounding or modifying factors. From the regression analysis five variables that had the strongest correlation with serum total cholesterol, HDL-cholesterol or HDL/total cholesterol ratio were entered as covariates in the analyses of covariance (ANCOVA).

\section{Results}

The average coffee consumption was higher in men than in women (table 1). This difference was seen ino each 10 year age group, and coffee consumption ${ }_{\odot}^{\circ}$ varied only slightly with age. Also the proportion of heavy coffee drinkers ( 10 cups or more per day) was more than twice as high in men as in women. About $5 \%$ of both men and women did not drink coffee at all.

The product moment correlation coefficients of coffee consumption with other selected variables ares shown in table 2. Smoking had the strongest and intake of saturated fats the second strongest (positive) association with coffee drinking. Findings in this

Table 2 Pearson correlation coeffecients between coffee or tea drinking (cups per day) and other selected variables in men and women

\begin{tabular}{|c|c|c|c|c|}
\hline \multirow[b]{2}{*}{ Variable } & \multicolumn{2}{|c|}{ Coffee drinking } & \multicolumn{2}{|c|}{ Tea drinking } \\
\hline & $\begin{array}{l}\text { Men } \\
(N=4072\end{array}$ & $\begin{array}{l}\text { Women } \\
(N=4230)\end{array}$ & Men & Women \\
\hline $\begin{array}{l}\text { Serum cholesterol } \\
\text { HDL-cholesterol } \\
\text { HDL/total cholesterol } \\
\text { Age } \\
\text { Body mass index } \\
\text { Dietary intake of } \\
\text { saturated fats } \\
\text { Smoking } \\
\text { Alcohol drinking } \\
\text { Fasting time } \\
\text { Physical activity } \\
\text { Use of sugar in } \\
\text { coffee or tea } \\
\text { Coffee or tea drinking }\end{array}$ & $\begin{array}{c}0.054 \\
\text { NS } \\
-0.040 \\
-0.033 \\
0.033 \\
\\
0.141 \\
0.280 \\
-0.034 \\
-0.065 \\
\text { NS }\end{array}$ & $\begin{array}{l}0.050 \\
\text { NS } \\
-0.046 \\
\text { NS } \\
0.096 \\
\\
0.149 \\
0.227 \\
\text { NS } \\
\text { NS } \\
0.074\end{array}$ & $\begin{array}{l}\text { NS } \\
0.032 \\
\text { NS } \\
0.023 \\
-0.122 \\
\\
0.253 \\
0.141 \\
-0.009 \\
-0.058 \\
0.065\end{array}$ & $\begin{array}{c}0.042 \\
\text { NS } \\
-0.053 \\
0.124 \\
\text { NS } \\
\\
0.269 \\
0.062 \\
-0.034 \\
\text { NS } \\
\text { NS }\end{array}$ \\
\hline
\end{tabular}

All coefficients shown were significant at $p<0.05$ level 
respect were similar for men and women. The correlation between coffee drinking and serum cholesterol was positive but rather weak.

Table 3 presents the mean values of coffee drinking in different categories of smoking habits and of tea drinking. Those men and women who had never smoked had the lowest consumption of coffee, and ex-smokers had the second lowest. Both male and female smokers also consumed more coffee than the others.

Only $4 \%$ of those men and women who did not drink coffee did not drink tea either. About $10 \%$ of men and $8 \%$ of women consumed more than 3 cups of tea per day. About $20 \%$ of these did not drink coffee at all. Thus, the majority of the tea drinkers were also coffee drinkers.

The mean serum total cholesterol levels in both age groups of 25 to 44 and 45 to 64 years were lowest in those men and women who did not drink coffee, at all (table 4). In the age group 25 to 44 years, in men and women, there was a linear increasing trend in the mean values of serum cholesterol with increasing amount of coffee consumed. In the older age group, 45 to 64 years, the peak level of serum cholesterol was found in those men and women who consumed 4 to 6 cups of coffee per day.

The mean serum cholesterol level adjusted for potential confounding factors in men was higher in those who consumed coffee compared to the coffeeabstainers (table 5). This difference was essentially the same in men and in women. Men who consumed only 1 to 3 cups of coffee per day had a slightly lower serum cholesterol level than those who consumed more. However, the serum cholesterol level did not increase with increasing amount of coffee consumption beyond 4 cups per day in men. Among coffee drinking women,

Table 3 Mean values of daily coffee consumption habits by smoking and tea drinking in men and women (\%)

\begin{tabular}{|c|c|c|c|c|}
\hline & \multicolumn{2}{|l|}{ Men } & \multicolumn{2}{|l|}{ Women } \\
\hline & \multicolumn{2}{|c|}{ Cups of coffee per day } & \multicolumn{2}{|c|}{ Cups of coffee per day } \\
\hline & $M e a n+S$ & $(N)$ & $M e a n+S$ & $(N)$ \\
\hline $\begin{array}{l}\text { Smoking } \\
\text { Never } \\
\text { Ex-smoker }\end{array}$ & $\begin{array}{l}4 \cdot 7+2 \cdot 8 \\
5 \cdot 3+3 \cdot 1\end{array}$ & $\begin{array}{r}(997) \\
(1898)\end{array}$ & $\begin{array}{l}4 \cdot 6+2 \cdot 3 \\
4 \cdot 7+2 \cdot 4\end{array}$ & $\begin{array}{r}(2916) \\
(862)\end{array}$ \\
\hline $\begin{array}{l}1-19 \text { times per day } \\
20 \text { or more times } \\
\text { per day }\end{array}$ & $\begin{array}{l}5 \cdot 5+2 \cdot 9 \\
7 \cdot 1+3 \cdot 6\end{array}$ & $\begin{array}{l}(696) \\
(934)\end{array}$ & $\begin{array}{l}5.5+2.7 \\
6.7+3 \cdot 4\end{array}$ & $\begin{array}{l}\text { (686) } \\
\text { (196) }\end{array}$ \\
\hline $\begin{array}{l}\text { Tea drinking } \\
\text { Not at all } \\
1-2 \text { cups per day } \\
3 \text { or more cups } \\
\text { per day }\end{array}$ & $\begin{array}{l}6 \cdot 3+3 \cdot 4 \\
3 \cdot 9+2 \cdot 4 \\
\\
3 \cdot 2+2 \cdot 6\end{array}$ & $\begin{array}{r}(1966) \\
(993) \\
(412)\end{array}$ & $\begin{array}{l}5 \cdot 3+2 \cdot 6 \\
3 \cdot 9+2 \cdot 0 \\
\\
2 \cdot 8+2 \cdot 4\end{array}$ & $\begin{array}{l}(2024) \\
(1360) \\
(324)\end{array}$ \\
\hline
\end{tabular}

Number of subjects in parentheses
Table 4 Crude mean serum total cholesterol level (mmolll) by coffee drinking, age, and sex

\begin{tabular}{llllll}
\hline $\begin{array}{l}\text { Consumption } \\
\text { of coffee } \\
\text { (cups per day) }\end{array}$ & Men & \multicolumn{3}{l}{ Women } \\
\cline { 2 - 3 } \cline { 5 - 6 } \cline { 5 - 6 } & $25-44 y r$ & $45-64 y r$ & & $25-44 y r$ & $45-64 y r$ \\
\hline 0 & 5.59 & 6.06 & & 5.26 & 6.23 \\
& $(109)$ & $(102)$ & & $(120)$ & $(95)$ \\
$1-3$ & 5.67 & 6.35 & & 5.36 & 6.59 \\
& $(473)$ & $(440)$ & & $(532)$ & $(547)$ \\
$4-6$ & 5.88 & 6.55 & & 5.41 & 6.75 \\
& $(997)$ & $(1108)$ & & $(1157)$ & $(1431)$ \\
$7-9$ & 5.91 & 6.43 & & 5.57 & 6.55 \\
& $(371)$ & $(299)$ & & $(280)$ & $(1431)$ \\
10 or more & 6.01 & 6.49 & & 5.56 & 6.64 \\
& $(358)$ & $(276)$ & $(148)$ & $(251)$ \\
Total & 5.85 & 6.47 & & 5.42 & 6.67 \\
& $(2308)$ & $(2275)$ & $(2237)$ & $(2452)$ \\
\hline
\end{tabular}

Number of subjects in parentheses

no correlation between serum cholesterol and daily consumption of coffee could be seen.

There was no association between coffee and HDLcholesterol in either men or women. The ratio of HDL/total cholesterol was slightly though significantly higher in men and women who did not drink coffee at all compared to coffee drinkers. Controlling for the five possible confounding factors did not remove the statistical significance of the differences detected.

Tea drinkers had slightly lower serum cholesterol levels compared to those who did not drink tea at all (table 6). After adjusting for the covariates, including coffee drinking, this difference was not statistically significant. In men, we found the highest HDLcholesterol level in those who drank more than 2 cups of tea per day, but in women the HDL-cholesterol was not associated with the amount of tea drinking. The ratio of $\mathrm{HDL} /$ total cholesterol was slightly but significantly higher in those men who consumed 3 or more cups of tea per day compared to the rest of the men.

\section{Discussion}

Our survey confirms that the Finns are heavy coffee drinkers. The proportion of people who did not drink coffee was very small, and the average daily consumption was much higher than in any other country. The most popular type of coffee consumed in Finland today is filtered coffee. The usual size of a coffee cup is about $150 \mathrm{ml}$ and it is customary to make coffee relatively strong. Finnish men drink more coffee than women in all age groups between 25 and 64 years. 
Table 5 Adjusted serum total cholesterol HDL-cholesterol, and ratio HDL/total cholesterol (mean $+S D)$ by coffee drinking in men and women

\begin{tabular}{|c|c|c|c|c|c|c|}
\hline \multirow[b]{2}{*}{$\begin{array}{l}\text { Coffee drinking } \\
\text { (cups per day) }\end{array}$} & \multicolumn{3}{|l|}{ Men } & \multicolumn{3}{|l|}{ Women } \\
\hline & $\begin{array}{l}\text { Total cholesterol } \\
\text { (mmol/l) }\end{array}$ & $\begin{array}{l}\text { HDL-cholesterol } \\
\text { (mmol/l) }\end{array}$ & $\begin{array}{l}\text { Ratio } \\
\text { HDL/total }\end{array}$ & $\begin{array}{l}\text { Total cholesterol } \\
\text { ( } \mathrm{mmol} / \mathrm{l})\end{array}$ & $\begin{array}{l}\text { HDL-cholesterol } \\
(\mathrm{mmol} / \mathrm{l})\end{array}$ & $\begin{array}{l}\text { Ratio } \\
\text { HDL/total }\end{array}$ \\
\hline $\begin{array}{l}0 \\
1-3 \\
4-6 \\
7-9 \\
10 \text { or more }\end{array}$ & $\begin{array}{l}5 \cdot 87+1 \cdot 11 \\
6 \cdot 06+1 \cdot 13 \\
6 \cdot 21+1 \cdot 21 \\
6 \cdot 14+1 \cdot 18 \\
6 \cdot 18+1 \cdot 22\end{array}$ & $\begin{array}{l}1 \cdot 22+0.33 \\
1.21+0.32 \\
1.21+0.30 \\
1.23+0.31 \\
1.23+0.31\end{array}$ & $\begin{array}{l}0.22+0.07 \\
0.21+0.07 \\
0.21+0.06 \\
0.21+0.07 \\
0.21+0.07\end{array}$ & $\begin{array}{l}5.83+1.29 \\
6.06+1.33 \\
6.10+1.37 \\
6.06+1.24 \\
6.09+1.31\end{array}$ & $\begin{array}{l}1.44+0.36 \\
1.44+0.33 \\
1.47+0.31 \\
1.47+0.31 \\
1.48+0.31\end{array}$ & $\begin{array}{l}0.26+0.07 \\
0.25+0.07 \\
0.25+0.07 \\
0.25+0.06 \\
0.25+0.07\end{array}$ \\
\hline $\begin{array}{l}\text { Total } \\
(\mathrm{N})\end{array}$ & $\begin{array}{l}6 \cdot 15+1 \cdot 19 \\
(4474)\end{array}$ & $\begin{array}{l}1.22+0.31 \\
(4133)\end{array}$ & $\begin{array}{l}0.21+0.07 \\
(4133)\end{array}$ & $\begin{array}{l}6.07+1.34 \\
(4495)\end{array}$ & $\begin{array}{l}1.46+0.33 \\
(4337)\end{array}$ & $\begin{array}{l}0.25+0.07 \\
(4337)\end{array}$ \\
\hline
\end{tabular}

*Adjusted for the following covariates: age, body mass index, saturated fat intake, smoking, fasting time, alcohol drinking, physical activity, sugar intake $\begin{array}{llllll}\text { ANCOVA main effect } p<0.001 & \text { NS } & p<0.05 & \text { NS }\end{array}$

Table 6 Adjusted serum total cholesterol, HDL-cholesterol, and ratio HDL/total cholesterol (mean $+S D)$ by tea drinking in men and women

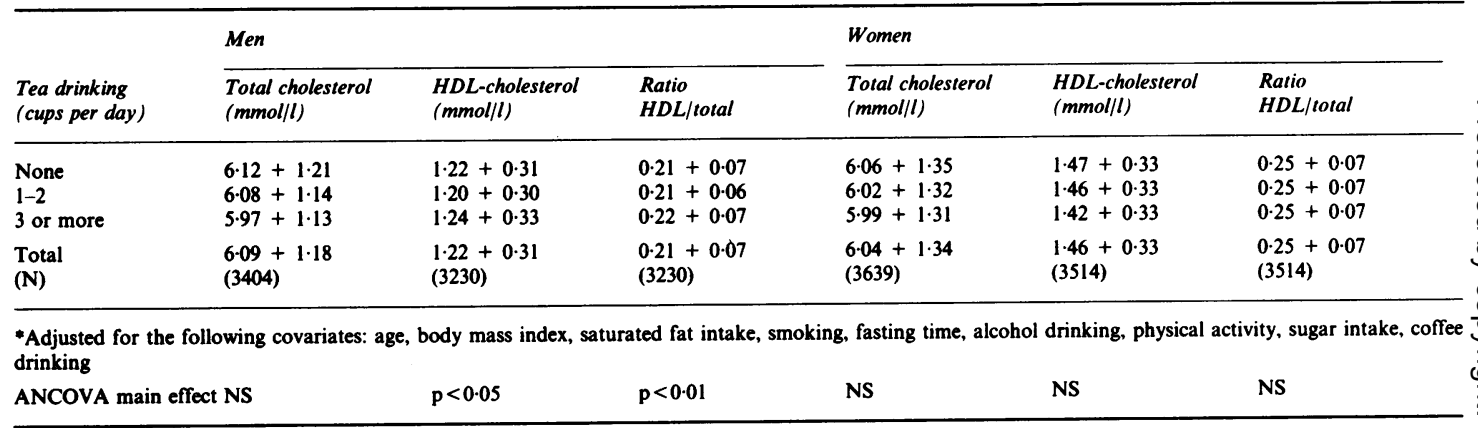

As expected, tea drinking correlated negatively with coffee drinking in our population. The overall level of tea drinking was relatively low, and the majority of tea drinkers consumed both tea and coffee.

According to our results, coffee consumption had a statistically significant but weak positive association with serum total cholesterol in both men and women. Thus coffee drinkers in general had higher serum cholesterol levels than non-drinkers. A similar finding has been reported recently by Kark and co-workers from Jerusalem in women, but the association was linear only in men. ${ }^{5}$ Some other studies have suggested a dose-relation in both sexes. ${ }^{313}$ The adjustment for possible confounding variables reduced this association but did not remove it. Contrary to the results from Tromsö, ${ }^{3}$ we did not find a linear association between these two variables. In the age group 25 to 44 years in our study, the crude mean values of serum cholesterol suggested a linear association. However, after controlling for the potential confounding factors no linear association was seen. Therefore, it is likely that the findings of studies suggesting a linear association were due to some confounding effects.

The conflicting results of the studies carried out so far raise several questions. Methodological problems are quite obvious. Only in five studies reported so far has the diet and especially the intake of fat been assessed and taken into account in the analyses. ${ }^{4571223}$ After proper adjustment for dietary factors the association between coffee consumption and serum cholesterol remained statistically significant only in women in the study by Mathias $e t$ $a l,{ }^{12}$ and in both men and women in the study carried out in Jerusalem. ${ }^{5}$ The study of Williams et al ${ }^{23}$ consisted only of middle-aged men and showed a significant association between serum cholesterol and coffee consumption after adjusting for several factors including diet.

In our study, the intake of saturated fats was measured in only a crude way as a score based mainly on qualitative questions. This limits the interpretation 
of the results. It is possible that a better adjustment for confounding dietary factors would have removed this weak association completely. It should also be noted that even if some association were left after proper adjustment for confounding dietary factors, the difference in actual serum cholesterol levels between coffee drinkers and abstainers would be very small indeed.

Another question raised by the Norwegian research group has been the brewing method used in making coffee. It was shown that more than 6 cups of traditionally brewed (boiled) but not filtered coffee raised serum cholesterol among healthy volunteers ${ }^{24}$ and men with hypercholesterolaemia. ${ }^{25}$ The type of coffee used in Finland is nowadays mostly filtered coffee but some rural communities still make brewed coffee. Unfortunately, the type of coffee was not ascertained in our survey. We have recently carried out a controlled trial, the results of which showed that it was brewed coffee that raised the serum cholesterol concentrations in hypercholesterolaemic patients. ${ }^{26}$

Our present data did not allow us to get reliable estimates on the intake of caffeine. It has been suggested that the possible positive association between coffee consumption and serum cholesterol is not due to caffeine but to some other substance in coffee. In a recent study in the United States, detailed information was collected about the intake of caffeine in people with mild hypertension, but no correlation between caffeine and serum cholesterol was found. ${ }^{14}$ However, in that study coffee consumption and serum cholesterol were positively associated. A recent prospective study comparing the effects of coffee, tea and a caffeine-free beverage did not find any effect of caffeine on serum cholesterol concentration. ${ }^{27}$

In conclusion, the results of this Finnish population study are in agreement with most studies from other countries in suggesting that there might be an association between coffee drinking and serum cholesterol concentration which cannot be fully explained by the confounding factors measured in the study. We are aware that the main dietary determinants for serum cholesterol are those related to fats, ${ }^{28}$ and that fat consumption was not quantitatively registered in either our study or in most previous studies on this subject. The association, after adjusting for qualitative saturated fat intake score, was, however, rather small and with more precise information on fat intake the association might have been further reduced. Thus the impact of coffee drinking on serum cholesterol, if any, seems to be small. To prove a causal relation a firm hypothesis of pathophysiological mechanisms involved would also be required. The results so far indicate only that the possible mechanisms do not include caffeine.
This study was supported by the Yrjö Jahnsson Foundation.

\section{References}

${ }^{1}$ Bjelke E. Colon cancer and blood cholesterol. Lancet 1974; i: $1116-7$.

${ }^{2}$ Rhoads GG, Kagan A, Yano K. Association between dietary factors and plasma lipoproteins. Circulation 1976; 54 (Suppl2): ii-53.

${ }^{3}$ Thelle DS, Arnesen E, Forde OH. The Tromsö Heart Study: Does coffee raise serum cholesterol? N Engl J Med 1983, 308: 1454-7.

${ }^{4}$ Haffner SM, Knapp JA, Stern MP, Hazuda HP, Rosenthal M, Franco LJ. Coffee consumption, diet and lipids. Am J Epidemiol 1985; 122: 1-12.

${ }^{5}$ Kark JD, Friedlander J, Kaumann NA, Stein Y. Coffee, tea and plasma cholesterol: the Jerusalem Lipid Research Clinic prevalence study. Br Med J 1985; 291: 699-704.

${ }^{6}$ Dawber TR, Kannel WB, Gordon T. Coffee and cardiovascular disease: observations from the Framingham study. $N$ Engl J Med 1974; 291: 871-4.

${ }^{7}$ Shekelle RB, Gale M, Paul O, et al. Coffee and cholesterol (letter). N Engl J Med 1983; 309: 1249-50.

${ }^{8}$ Kovar MG, Fulwood R, Feinlieb M. Coffee and cholesterol (letter). N Engl J Med 1983: 309: 1249.

${ }^{9}$ Hofman A, Van Leer A, Klein F, et al. Coffee and cholesterol (letter). N Engl J Med 1983; 309: 1249.

${ }^{10}$ Nichols AB, Ravenscroft C, Lampier DE, et al. Independence of serum lipid levels and dietary habits: The Tecumseh Study. JAMA 1976; 236: 1948-53.

${ }^{11}$ Shilow M, Mathers C. Caffeine consumption and serum cholesterol levels. Int J Epidemiol 1984; 13: 422-70

12 Mathias S, Garland C, Barret-Connor E, Wingard DL. Coffee, plasma cholesterol and lipoproteins. Am $J$ Epidemiol 1985; 121: 896-905.

13 Klatsky AL, Petitti DB, Armstrong MA, Friedman GD. Coffee, tea and cholesterol. Am J Cardiol 1985; 55: 577-8.

14 Heyden S, Heiss G, Manegold D, et al. The combined effect of smoking and coffee drinking on LDL and HDL cholesterol. Circulation 1979; 60: 22-5.

${ }^{15}$ Arab L, Kohlmeier G, Schlierf G, et al. Coffee and cholesterol (letter). $N$ Engl J Med 1983; 309: 1250.

16 Little JA, Shanoff HM, Csima A, et al. Coffee and serum lipids in coronary heart disease. Lancet 1966; i: 732-4.

${ }^{17}$ Statistical yearbook of Finland 1984. Helsinki: Government Printing Agency, 1985.

${ }^{18}$ Puska P, Salonen JT, Nissinen A, et al. Change in risk factors for coronary heart disease during 10 years of a community intervention programme (North Karelia Project). Br Med J 1983; 287: 1840-4.

19 Tunstall-Pedoe H. Monitoring trends in cardiovascular disease and risk factors: the WHO "Monica" project. WHO Chronicle 1985; 39: 3-5.

${ }^{20}$ Salonen JT, Puska P, Kottke TE, et al. Coronary risk factor clustering patterns in eastern Finland. Int $J$ Epidemiol 1981; 10: 203-10.

${ }^{21}$ Salonen JT, Tuomilehto J, Puska P. The relation of physical activity changes to changes in serum cholesterol and body weight in a three-year follow-up of population sample. Scand J Soc Med 1981; 9: 109-17.

22 Kostner, GM. Enzymatic determination of cholesterol in high density lipoprotein fractions prepared by polyanion precipitation. Clin Chem 1976; 22 : 695. 
${ }^{23}$ Williams PT, Wood PD, Vranizan KM, Albers JJ, Garay SC, Taylor CB. Coffee intake and elevated cholesterol and apolipoprotein B levels in men. JAMA 1985; 253: 1407-11.

${ }^{24}$ Arnesen E, Forde $\mathrm{OH}$, Thelle DS. Coffee and serum cholesterol. Br Med J 1984; 288: 1960.

${ }^{25}$ Forde OH, Knutsen SF, Arnesen E, Thelle DS. The Tromsö heart study: Coffee consumption and serum lipid concentrations in men with hypercholesterolaemia: a randomised intervention study. $\mathrm{Br} \mathrm{Med} J$ 1985; 290: 893-95.
${ }^{26}$ Aro A, Tuomilehto J, Kostiainen E, Uusitalo U, Pietinen P. Boiled coffee increases serum low-density lipoprotein concentration. Metabolism (in press).

${ }^{27}$ Aro A, Kostiainen E, Huttunen JK, Seppala E, Vapaatalo H. Effects of coffe and tea on lipoproteins and prostanoids. Atherosclerosis 1985; 57: 123-8.

${ }^{28}$ Grundy SM, Bilheimer D, Blackburn H, et al. Rationale of the Diet-Heart Statement of the American Heart Association. Report of Nutrition Committee. Circulation 1982; 65: 839-54.

\section{Corrections}

Jarrett RJ, Keen H, Murrells T. Changes in blood pressure and body weight over ten years in men selected for glucose intolerance.

\section{J Epidemiol Comm Health 1987; 41: 145-51.}

On page 150, the two lines below formula (2) should read:

where $\lambda=$ average $\left(s^{2}\right) / \operatorname{Var}\left(m^{\prime}\right), a_{1}=\bar{t} / \sum_{i=1}^{k}\left(t_{i}-\bar{t}\right)^{2}$

and $\mathrm{a}^{2}=\sum_{\mathrm{i}=1}^{\mathrm{k}} \mathrm{t}_{\mathrm{i}}{ }^{2} / \mathrm{k}_{\mathrm{i}=1}^{\mathrm{k}}\left(\mathrm{t}_{\mathrm{i}}-\overline{\mathrm{t}}\right)^{2}$.

Formula (3) should read

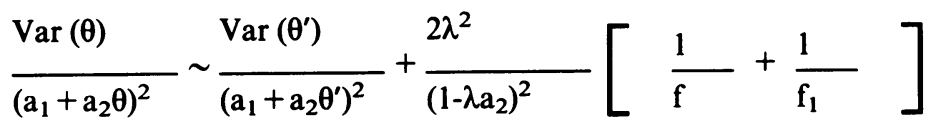

On the third line of the subsequent paragraph w' should be w'.

In the right hand side of the appendix table under the headings 'Adjusted regression coefficients' $\theta$ ' should be $\theta$. 